\title{
Cloning and characterization of the ColE7 plasmid
}

\author{
KIN-F. CHAK, ${ }^{1 *}$ WhITE-S. KUO, ${ }^{1}$ Fong-M. LU ${ }^{1}$ and R. JAMES ${ }^{2}$ \\ ${ }^{1}$ Department of Biochemistry, National Yang-Ming Medical College, Shih-Pai, Taipei, Taiwan 112, ROC \\ ${ }^{2}$ School of Biological Sciences, University of East Anglia, Norwich NR4 7TJ, UK
}

(Received 4 June 1990; revised 27 August 1990; accepted 12 September 1990)

\begin{abstract}
The $6.2 \mathrm{~kb}$ ColE7-K317 plasmid was mapped and the DNA fragments of the colicin E7 operon subcloned into pUC18 and pUC19. The size of the functional colicin E7 operon deduced by subcloning was $2 \cdot 3 \mathrm{~kb}$. The colicin E7 gene product was purified by carboxymethylcellulose chromatography. Both colicin E7 and E9 were demonstrated to exhibit a non-specific DNAase-type activity by in vitro biological assay. The molecular mass of colicin E7 was $61 \mathrm{kDa}$, as determined by SDS-PAGE. From DNA sequence data, the estimated sizes of the E7 immunity protein and the E7 lysis protein were $9926 \mathrm{Da}$ and $4847 \mathrm{Da}$, respectively. Comparison of restriction maps and DNA sequence data suggests that ColE7 and ColE2 are more closely related than other $\mathbf{E}$ colicin plasmids.
\end{abstract}

\section{Introduction}

The E-group colicins are a group of plasmid-borne bacteriocins (Fredericq, 1949) which exhibit antibioticlike inhibition of bacterial growth. The activity spectrum of colicins is confined to closely related organisms such as Escherichia, Salmonella and Shigella strains (the Enterobacteriaceae). The E-group colicins have been subdivided into colicins E1 to E9 on the basis of immunity tests (Watson et al., 1981; Cooper \& James, 1984). The modes of action of some E-group colicins are well documented (Konisky, 1982). Colicin El exhibits an ionophore effect on the membrane of target cells (Tokuda \& Konisky, 1979), colicin E3 is an RNAase (Bowman et al., 1971), and colicins E2 and E8 are DNAases (Schaller \& Nomura, 1976; Toba et al., 1988).

The production of $\mathrm{E}$ colicins is controlled and regulated by a set of genes on the plasmid forming an 'SOS' response operon which includes structural (cea), immunity (cei) and lysis/release ( $\mathrm{cel}$ ) genes. The production of colicin is inducible by DNA damage of the host cell, which can be induced by mitomycin $\mathrm{C}$ or UV irradiation (Herschman \& Helinski, 1967). The synthesis of the immunity gene protein appears to be constitutive (Jakes et al., 1974). The lysis gene is promoterless (Chak \& James, 1985), its transcription relying upon transcriptional readthrough from the promoter of the colicin

Abbreviation: MC, mitomycin C.

The nucleotide sequence data reported in this paper have been submitted to GenBank and assigned the accession number M57540. structural gene (Chak \& James, 1985). In previous studies of the ColE3-CA38 and the ColE9-J plasmids, a second unrelated immunity gene, encoding immunity to colicin E8 (Chak \& James, 1984) and E5 (Chak \& James, 1986), and located distal to the E3-cei and E9-cei genes, respectively, was identified.

In this report, we present the genetic organization of the ColE7 plasmid and the DNA sequence of E7-cei and E7-cel, and verify the mode of action of colicin E7 by an in vitro biological assay.

\section{Methods}

Bacterials strains, plasmids and media. Escherichia coli W3110(ColE7K317), E. coli(ColE8-J) and E. coli(ColE9-J) were from the collection of Dr R. James. Plasmids pUC18 and pUC19 (Yanisch-Perron et al., 1985) were used as cloning vectors. E. coli W 3110 was used as a standard strain for colicin production and immunity tests. $E$. coli JM101 and HB101 were used as cloning hosts. A pair of promoterprobe vectors, pKC 86 and pKC87 (Chak \& James, 1985), were used for promoter activity tests of the recombinant plasmids. E. coli JC3272 (his lys trp lac $\mathrm{Y}$ galK strA) was used as the host for the promoter-probe vectors. Details of the construction of recombinant plasmids and derivatives are shown in Table 1.

Bacteria were cultured at $37^{\circ} \mathrm{C}$ in L-broth (Miller, 1972). For selection of recombinant clones, ampicillin was included in L-agar at a final concentration of $100 \mu \mathrm{g} \mathrm{ml}^{-1}$. The chromogenic substrate 5bromo-4-chloro-3-indolyl $\beta$-D-galactoside (X-Gal) and isopropyl $\beta$-Dthiogalactoside (IPTG) were added to the plates at a final concentration of $20 \mu \mathrm{g} \mathrm{ml}^{-1}$ to select pUC18 or pUC19 recombinants.

Enzymes and reagents. Restriction enzymes and T4 DNA ligase were purchased from Bethesda Research Labs, Boehringer Mannheim, Promega Corporation or Toyobo Co. Mitomycin C (MC) was obtained from Sigma. 
Table 1. Derivation of recombinant plasmids

\begin{tabular}{|c|c|}
\hline Plasmid & Derivation \\
\hline pHK 101 & $\begin{array}{l}\text { The whole } 6 \cdot 2 \mathrm{~kb} \text { ColE7-K } 317 \text { linearized fragment } \\
\text { cloned into the EcoRI site of pUC18 }\end{array}$ \\
\hline pHK202 & $\begin{array}{l}\text { Same as pHK } 101 \text {, but with the insert in the } \\
\text { opposite orientation }\end{array}$ \\
\hline pHK001 & $\begin{array}{l}\text { The } 5.0 \mathrm{~kb} E c o \mathrm{RI}-\mathrm{Bg} / \mathrm{II} \text { fragment of ColE7 cloned } \\
\text { into the EcoRI-BamHI sites of pUC18 }\end{array}$ \\
\hline pHK 14 & The $1.6 \mathrm{~kb}$ Sau $3 \mathrm{~A}$ fragment of $\mathrm{pHK} 101$ deleted \\
\hline pHK 25 & $\begin{array}{l}\text { The } 0.75 \mathrm{~kb} \text { Sau3A fragment of ColE7 cloned into } \\
\text { the Bam HI site of pUC18 }\end{array}$ \\
\hline pHK 80 & $\begin{array}{l}\text { The } 0.65 \mathrm{~kb} \text { Sau3A fragment of ColE7 cloned into } \\
\text { the Bam HI site of pUC19 }\end{array}$ \\
\hline pHK80-R & $\begin{array}{l}\text { As pHK } 80 \text {, but with the insert in the opposite } \\
\text { orientation }\end{array}$ \\
\hline pHK80-P10 & $\begin{array}{l}\text { The } 0.32 \mathrm{~kb} \text { DraI-Sau } 3 \mathrm{~A} \text { fragment of pHK } 80 \\
\text { deleted }\end{array}$ \\
\hline pHK80-E4 & $\begin{array}{l}\text { The } 0.34 \mathrm{~kb} \text { Sau } 3 \mathrm{~A}-D r a \mathrm{I} \text { fragment of pHK } 80 \\
\text { deleted }\end{array}$ \\
\hline pSE4 & $\begin{array}{l}\text { The linearized } 6.2 \mathrm{~kb} E c o \text { RI fragment of ColE7 } \\
\text { was partially restricted with } D r a \mathrm{l} \text {, and the } \\
\text { resulting restriction fragments were then cloned } \\
\text { into the EcoRI-SmaI sites of pUC18; the } 1.3 \mathrm{~kb} \\
\text { DraI-EcoRI fragment is present in this } \\
\text { recombinant }\end{array}$ \\
\hline pSE5 & $\begin{array}{l}\text { Subcloning method as for pSE4; the } 1.8 \mathrm{~kb} \text { DraI- } \\
\text { EcoRI fragment is present in this recombinant }\end{array}$ \\
\hline pSE3 & $\begin{array}{l}\text { Subcloning method as for pSE4; the } 2.9 \mathrm{~kb} \mathrm{DraI}- \\
\text { EcoRI fragment is present in this recombinant }\end{array}$ \\
\hline pSB57 & $\begin{array}{l}\text { pHK001 was linearized by } B g l \mathrm{II} \text {, then partially } \\
\text { restricted with } D r a \mathrm{I} \text {. After self-ligation, three } \\
\text { deletion mutants were obtained; a } 4 \cdot 2 \mathrm{~kb} \text { DraI- } \\
B g / \mathrm{II} \text { fragment was deleted in pSB57 }\end{array}$ \\
\hline pSB64 & $\begin{array}{l}\text { Subcloning method as for pSB57; a } 3.2 \mathrm{~kb} \mathrm{DraI-} \\
\text { BglII fragment was deleted from recombinant } \\
\text { pHK001 }\end{array}$ \\
\hline pSB58 & $\begin{array}{l}\text { Subcloning method as for pSB57; a } 2.4 \mathrm{~kb} \text { DraI- } \\
\text { BglII fragment should have been deleted from } \\
\text { recombinant pHK001, but the deletion was } \\
\text { slightly shorter than expected }\end{array}$ \\
\hline pPPV-57 & $\begin{array}{l}\text { The } 2 \cdot 1 \mathrm{~kb} B g l \mathrm{II}-\mathrm{DraI} \text { fragment from } \mathrm{pBS} 57 \text { was } \\
\text { cloned into the Bam HI-SmaI site of pKC } 86\end{array}$ \\
\hline pPPV-57R & $\begin{array}{l}\text { As pPPV-57, but the } 2 \cdot 1 \mathrm{~kb} \mathrm{BglII}-D r a I \text { fragment } \\
\text { was cloned into pKC } 87\end{array}$ \\
\hline pPPV-EHI & $\begin{array}{l}\text { A } 0.85 \mathrm{~kb} \text { fragment, containing the } 5 \text { terminus of } \\
\text { ColE7, from pHK } 14 \text { was released by restriction } \\
\text { with } X b a \mathrm{I} \text { and } H i n c I I \text {, then this fragment was } \\
\text { subcloned into the } X b a I-S m a I \text { site of pKC } 86\end{array}$ \\
\hline pPPV-EHIR & $\begin{array}{l}\text { As pPPV-EHl, but the } 0.85 \mathrm{~kb} \text { fragment was } \\
\text { cloned into pKC } 87\end{array}$ \\
\hline pPPV80 & $\begin{array}{l}\text { The } 0.65 \mathrm{~kb} \text { Sau } 3 \mathrm{~A} \text { fragment was released from } \\
\text { pHK } 80 \text { by restriction with HindIII and EcoRI, } \\
\text { and this fragment was subcloned into the } \\
\text { HindIII-EcoRI site of pKC } 86\end{array}$ \\
\hline pPPV80R & $\begin{array}{l}\text { As pPPV80, but the } 0.65 \mathrm{~kb} \text { fragment was cloned } \\
\text { into pKC } 87\end{array}$ \\
\hline pPPV80-P10 & $\begin{array}{l}\text { The } 0.32 \mathrm{~kb} \text { DraI-Sau3A fragment was released } \\
\text { from pHK } 80-\mathrm{P} 10 \text { by restriction with HindIII and } \\
\text { EcoRI, and the fragment was subcloned into the } \\
\text { HindIII-EcoRI site of pKC } 86\end{array}$ \\
\hline pPPV80-P10R & $\begin{array}{l}\text { As pPPV80-P10, but the fragment was cloned into } \\
\text { pKC } 87\end{array}$ \\
\hline pPPV80-E4 & $\begin{array}{l}\text { The } 0.34 \text { kb Sau3A-DraI fragment from pHK } 80- \\
\text { E4 was released by restriction with HindIII and } \\
\text { EcoRI, and the fragment was subcloned into the } \\
\text { HindIII-EcoRI site of pKC } 86\end{array}$ \\
\hline pPPV80-E4R & $\begin{array}{l}\text { As pPPV80-E4, but the fragment was cloned into } \\
\text { pKC } 87\end{array}$ \\
\hline
\end{tabular}

Nucleotide sequencing. The nucleotide sequence of the cei and cel genes of the ColE7 plasmid was determined by the method of Sanger $e t$ al. (1977). The double-stranded DNA sequencing method was that described by Chen \& Seeburg (1985). Modified T7 DNA polymerase (Tabor \& Richardson, 1987) was used for polymerization of nucleotides in our nucleotide sequence determination. $\left[\alpha^{-35}\right.$ S $] \mathrm{dATP}$ was obtained from Amersham. The 17-mer forward and reverse pUC/M13 sequencing primers were purchased from Promega Biological Research Products. PC/Gene, a DNA sequence analysis program from Genetech, was used for the analysis of the DNA sequences.

Preparation of colicin extracts, and colicin production and immunity tests. These were performed as previously described (Chak \& James, 1984).

Colicin titre assay. The preparation of colicin extracts for titre assay was as previously described (Chak \& James, 1984). Colicin titres were determined by the method of Reeves (1965) with some modifications. Two-fold serial dilutions of colicin extract were made from $2^{\circ}$ to $2^{35}$ in L-broth, containing the appropriate antibiotic, in a microtitre dish. Then $10 \mu$ l of each diluted colicin extract was spotted on an L-agar plate which was overlaid with $3 \mathrm{ml}$ soft L-agar containing $100 \mu \mathrm{l}$ of the indicator culture (E. coli W3110). Plates were incubated overnight at $37^{\circ} \mathrm{C}$. The clear or turbid zones resulting from the inhibition of cell growth by the diluted colicin extracts were recorded. The number of clear or turbid zones was plotted against the reciprocal of the corresponding dilution factor. Cell survival followed a sigmoidal-like curve as the colicin dilution increased. The colicin titre was defined as the reciprocal of the dilution that killed $50 \%$ of the cells as measured from the survival curve (Reeves, 1965).

Promoter activity test. Two promoter-probe vectors, pKC86 and pKC87 (Chak \& James, 1985), were used to detect the promoter strength of the cloned fragment present in recombinant plasmids. The galactokinase assay was as previously described (McKenny et al., 1981), with some modifications: in the induction experiments, cultures containing recombinant plasmids were grown to an $\mathrm{OD}_{650}$ of 0.4 before the addition of $\mathrm{MC}\left(0.5 \mu \mathrm{g} \mathrm{ml}^{-1}\right)$; and $5 \mu \mathrm{l}$, instead of $20 \mu \mathrm{l}$, of galactokinase extract was used.

Plasmid isolation, restriction, ligation and transformation. Plasmids were prepared by the method of Birnboim (1983). Digestion of DNA with restriction endonucleases, ligation of DNA fragments and transformation of competent cells were carried out as described by Maniatis et al. (1982).

Electrophoresis of DNA and purification of fragments. Electrophoresis of DNA fragments was performed as previously described (Chak \& James, 1984). Specific fragments were recovered from gels using the method of Dretzen et al. (1981).

Purification of colicins. The purification of colicins, using carboxymethylcellulose chromatography after acidic precipitation, was as described by Pugsley \& Oudega (1987). The crude extracts of colicin E7 and colicin E9 were prepared from 5 litres of culture medium as previously described (Chak \& James, 1984). Cell debris was removed by centrifugation and the crude colicin was then precipitated by ammonium sulphate $(60 \%$ saturation $)$. The precipitate was resuspended in $50 \mathrm{ml} 10 \mathrm{~mm}$-potassium phosphate buffer $(\mathrm{pH} 7.0)$ and dialysed overnight against 5 litres of the same buffer. The colicin solution was centrifuged at $20000 \mathrm{~g}$ for $10 \mathrm{~min}$ and the supernatant fraction was applied to a carboxymethylcellulose column. The column was rinsed for several hours with the same buffer until all unbound material was eluted. The colicin fraction was then eluted with a linear salt gradient of 1.5 bed volumes from 0 to $400 \mathrm{~mm}-\mathrm{NaCl}$ in phosphate buffer ( $\mathrm{pH} \mathrm{7.0)}$. Fractions were monitored for protein, by measuring $A_{280}$, and for colicin activity. The fractions containing the highest 
concentration of colicin were pooled and dialysed overnight against several changes of distilled water at $4{ }^{\circ} \mathrm{C}$. Finally, purified colicin was lyophilized and stored at $-20^{\circ} \mathrm{C}$. The purity of the colicin preparation was checked by SDS-PAGE.

In vitro biological activity assay of purified colicins. Approximately $2 \mu \mathrm{g}$ of CsCl-purified pUC18 DNA was dissolved in reaction buffer $(20 \mathrm{mM}$ Tris/ $\mathrm{HCl} \mathrm{pH} 8 \cdot 0,80 \mathrm{mM}-\mathrm{NaCl}, 10 \mathrm{mM}-\mathrm{MgSO}_{4}$ ). After the addition of $1 \mu \mathrm{g}$ purified colicin to the reaction mixture, sterile distilled water was added to a final volume of $40 \mu \mathrm{l}$. The reaction mixture was then equally distributed into four tubes, which were incubated at $37^{\circ} \mathrm{C}$. After 0,30 , 60 and $90 \mathrm{~min}, 1 \mu \mathrm{l} 250 \mathrm{~mm}$-EDTA was added to one tube. After all samples had been collected, the plasmid DNA was analysed by $0.8 \%$ agrose gel electrophoresis. The mixture in the control tube was the same as all other sampling tubes except that colicin was not included.

\section{Results}

Restriction endonuclease mapping and cloning of the ColE7 plasmid

After restriction endonuclease digestion of the ColE7K317 plasmid with DraI, three fragments, of 4.6, 1.1 and $0.5 \mathrm{~kb}$, were obtained (data not shown). The size of ColE7-K317 was therefore estimated to be around $6.2 \mathrm{~kb}$. Unique $E c o \mathrm{RI}, B g l \mathrm{II}$, and $C l a \mathrm{I}$ restriction sites were located in the $4.6 \mathrm{~kb}$ DraI fragment by double digests (Fig. 1). Three HindII sites were also mapped on the plasmid (Fig. 1). No sites were found for BamHI, HindIII, PstI, SmaI or SacI.

The unique EcoRI site of the ColE7 plasmid was cleaved and the linearized DNA fragment was ligated into the EcoRI site of the cloning vector pUC18. Two different orientations of the insert were obtained in recombinant plasmids pHK101 and pHK201, respectively (Fig. 2).

\section{Subcloning and localization of the colicin operon of the ColE7 plasmid}

In order to generate more subclones of the ColE7 plasmid, we adopted the site-specific deletion method by partially digesting the ColE7 plasmid with $\mathrm{DraI}$ and then completely digesting the DNA with $E c o$ RI or $B g l$ III. The resulting fragments were cloned into the EcoRI/ SmaI or BamHI/SmaI sites respectively, of pUC18. The resulting recombinant plasmids are shown in Fig. 2 . The new recombinant plasmids generated by the deletion of DraI fragments, namely pSE3, pSE4, pSE5, pSB57 and pSB64, were obtained as expected (Fig. 2). Recombinant plasmid pSB58 (Fig. 2) was shorter than expected; the reason for this is not known. Three more subclones, pHK 14, pHK25 and pHK80, were obtained by ligating the partially restricted Sau3A fragments of the ColE7 plasmid into the BamHI site of pUC18 (Fig. 2).

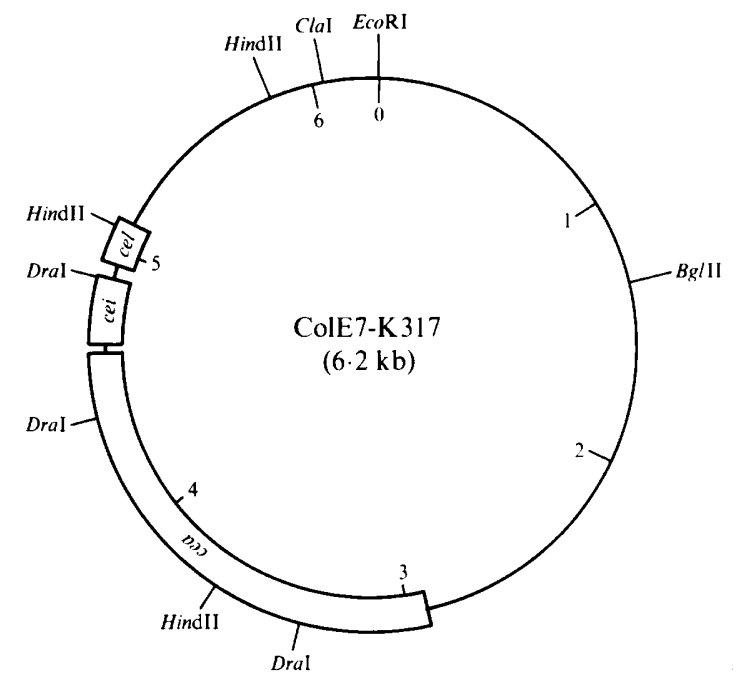

Fig. 1. Circular restriction map of the ColE7-K317 plasmid. The unique $E c o$ RI site was used as $0 \mathrm{~kb}$ of the map; the $C l a \mathrm{I}$ and $B g l \mathrm{II}$ sites were also unique. The boxes represent the region of the cea, cei and cel genes of the colicin E7 operon. Restriction sites for BamHI, HindIII, Pst I, SmaI and SacI were not found in this plasmid.

Recombinant pHK001 was obtained by subcloning the large $E c o$ RI-BglII fragment of the ColE7 plasmid into the EcoRI/BamHI sites of pUC18.

The results of the phenotypic testing of cultures carrying these recombinant plasmids for colicin production and immunity are shown in Fig. 2. Cultures harbouring pHK 14 or pHK001 were immune to colicin E7 as well as producing colicin E7. On plates overlaid with $E$. coli W3110, E. coli(pHK001) produced a larger clear zone than $E$. coli(pHK 14). This suggested that the Sau3A fragment deleted from pHK 14 may affect colicin production. E. coli(pHK80) was immune to colicin E7 (Fig. 2). This showed that the gene encoding the immunity protein is completely located on this Sau3A fragment. In order to locate the immunity protein gene more precisely, pHK 80 was restricted with EcoRI and Pst I to isolate the $0.65 \mathrm{~kb} \mathrm{Sau} 3 \mathrm{~A}$ fragment (Fig. 3) from the recombinant plasmid. The purified fragment was then cleaved with DraI and subcloned into either the EcoRI/SmaI or the PstI/SmaI sites of pUC18, to give the recombinant plasmids pHK $80-\mathrm{P} 10$ and pHK80-E4 (Fig. 3). $E$. coli(pHK 80-P10) was immune to colicin E7, but $E$. coli(pHK 80-E4) was not. This demonstrated that the immunity protein gene of the ColE7 plasmid was on the $0.34 \mathrm{~kb}$ fragment of the recombinant pHK 80-P10. This result has been confirmed by DNA sequencing of this region (see Fig. 5).

In previous studies (Chak \& James, 1985), the cel gene of other E colicin plasmids was localized in tandem with the cei gene. However, $E$. coli(pHK80) did not exhibit cell lysis even when the lac promoter of pUC18 was induced by IPTG (data not shown). We speculated that 


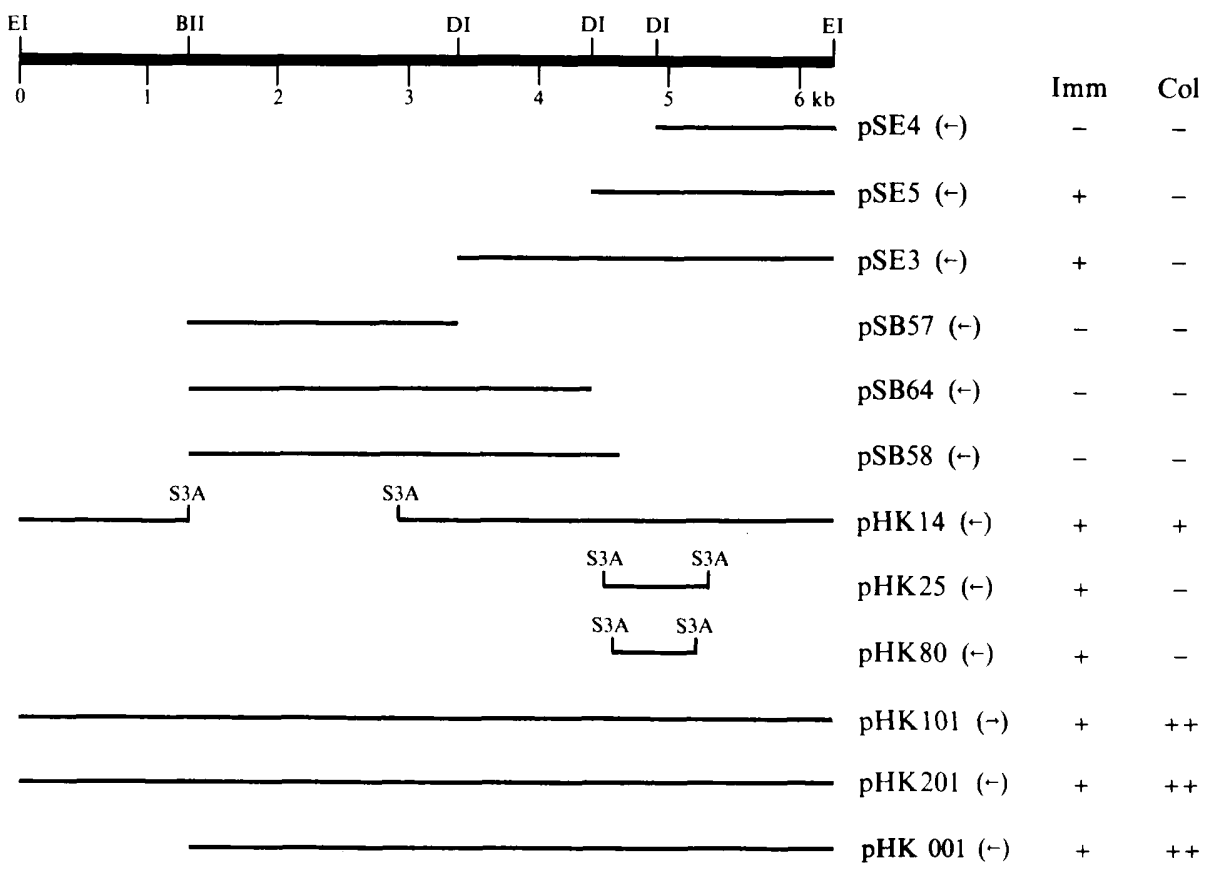

Fig. 2. Localization and characterization of the colicin E7 operon. Details of the construction of these subclones are described in the text and in Table 1. The thicker line at the top represents the $6.2 \mathrm{~kb}$ linearized restriction map of the ColE7 plasmid. The arrows in parentheses show the orientation of the promoter of the cloning vector, pUC18. S3A, Sau3A; BII, BglII; DI, DraI; EI, EcoRI. Imm and $\mathrm{Col}$ stand for immunity and colicin production phenotypes, respectively. The symbol + indicates the subclones which confer immunity to colicin E7, or produce colicin in the production test $(++$ indicates a strong effect), whilst the symbol - represents a negative result in these two in vivo tests.

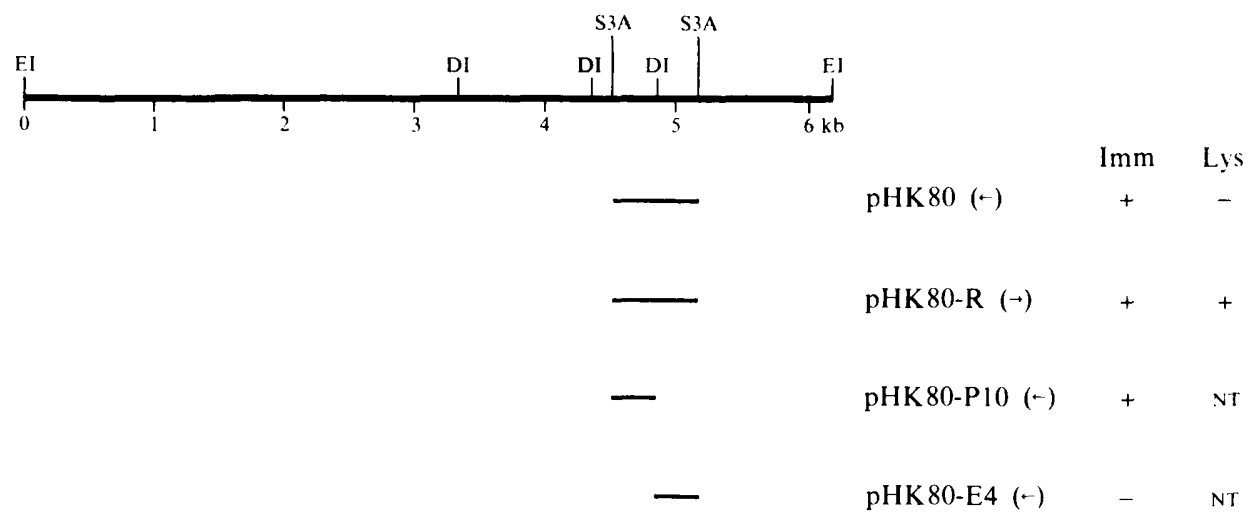

Fig. 3. Identification of the DNA fragment of the colicin E7 operon responsible for immunity and cell lysis. Detailed cloning methods are described in the text and in Table 1. Symbols and abbreviations are the same as in Fig. 2; Lys, test for IPTG induction of cell lysis (NT, not tested).

the $0.65 \mathrm{~kb}$ fragment of recombinant $\mathrm{pHK} 80$ was in the wrong orientation with respect to the lac promoter. In order to prove this, the $0.65 \mathrm{~kb}$ insert from recombinant pHK 80 was released by digestion with both EcoRI and $H i n d I I I$, and the fragment was ligated into the EcoRI and HindIII sites of pUC19. To avoid the occurrence of cell lysis, no IPTG was added to the selective plate for screening of recombinant plasmids. As judged by the size of the insert, recombinant pHK80-R (Fig. 3) was identified as carrying the $0.65 \mathrm{~kb}$ DNA fragment from pHK80. When the lac promoter of E. coli JM101(pHK80-R) was induced by IPTG, cell lysis started $60 \mathrm{~min}$ after induction. This result demonstrated that the $0.65 \mathrm{~kb}$ fragment contained genes for both the immunity 


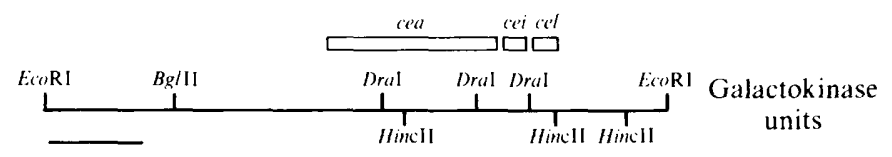

pPPV57
pPPV57R
pPPV-EH1
pPPV-EH1R
pPPV80
pPPV80R
pPPV80-P10
pPPV80-P10R
pPPV80-E4
pPPV80-E4R
pKC86
pKC87

protein and the lysis protein. The position of the cel gene was confirmed by DNA sequencing of this fragment (see Fig. 5).

\section{Assay of colicin titre from $E$. coli harbouring recombinant plasmids}

E. coli(pHK001) produced a much larger clear zone ( $7.5 \mathrm{~mm}$ in diameter) on a plate seeded with the indicator strain, E. coli W3110, than did E. coli harbouring the recombinant plasmid pHK14 $(2 \mathrm{~mm})$ (Fig. 2). To measure the amount of colicin produced from these two $E$. coli strains, a quantitative assay of colicin was performed (see Methods).

From the survival curve (data not shown), the titre of colicin produced by $E$. coli(pHK001) was $2^{17.5}$ (equal to $1.9 \times 10^{5}$ ), which was in agreement with the titre assay of colicin E3 produced from $E$. coli(pKC11) (Chak \& James, 1984) using similar assay conditions. However, due to the very low colicin production of E. coli( $\mathrm{pHK} 14)$, the titre of the colicin produced by this $E$. coli strain could not be determined by this assay method. The formation of a very small clear zone by this strain in the stab assay suggested that this strain only produces the basal level of colicin, with or without MC induction.

\section{Promoter activity test of the colicin E7 operon}

The DNA fragments which might contain promoters along the colicin E7 operon were cloned into the promoter-probe vectors pKC86 and pKC87 (Fig. 4). Without MC induction, the promoter activity of recombinant plasmid pPPV80-P10 was 38 galactokinase units (Fig. 4). However, no promoter activity was detected from the recombinant plasmid pPPV80-E4. This implied that the former recombinant contains the cei promoter, whereas the latter recombinant, which contains the cel gene, does not have its own promoter. Furthermore, no promoter activity could be detected from the recombinant pPPV80, even though $E$. coli harbouring this plasmid is immune to colicin E7. The reason for this will be discussed later. Under the same conditions, the promoter activity of the recombinants pPPV-57 and pPPV-EH1 was 25 and 22 galactokinase units, respectively (Fig. 4). This indicated that, without induction, the promoter activity of the cei gene is stronger than that of the cea gene.

When $E$. coli harbouring recombinant pPPV-57 was induced with $\mathrm{MC}$ at $0.5 \mu \mathrm{g} \mathrm{ml}^{-1}$, the promoter activity was increased from the basal level (20-30 units) to over 400 units within $2 \mathrm{~h}$ (data not shown). In contrast, the promoter activity of recombinant pPPV-EH1 under MC induction was the same as the basal activity. This implied that the DNA fragment which was deleted from the upstream region of the colicin operon in recombinant pPPV-EH1 may be important for the 'SOS' response.

\section{Nucleotide sequence of the cei and cel genes of the ColE7 plasmid}

The recombinant plasmids pHK80-P10 and pHK80-E4 (Fig. 3) were used to determine the nucleotide sequence of the $c e i$ and $c e l$ genes of the ColE7 plasmid. A sequence of $659 \mathrm{bp}$, which included cei and cel, and a part of the 3' end of the colicin E7 gene, was determined (Fig. 5). The sizes of the cei and cel genes determined by the ORFs were $261 \mathrm{bp}$ and $141 \mathrm{bp}$, respectively. The sequence data further confirmed the finding that the cei and cel genes were located in plasmids pHK80-P10 and pHK80-E4, respectively (Fig. 3). From the sequence data, it was noticed that the last three codons (AAA, CAG and GGC) of $c e i$ in the plasmid pHK80-P10 were not 


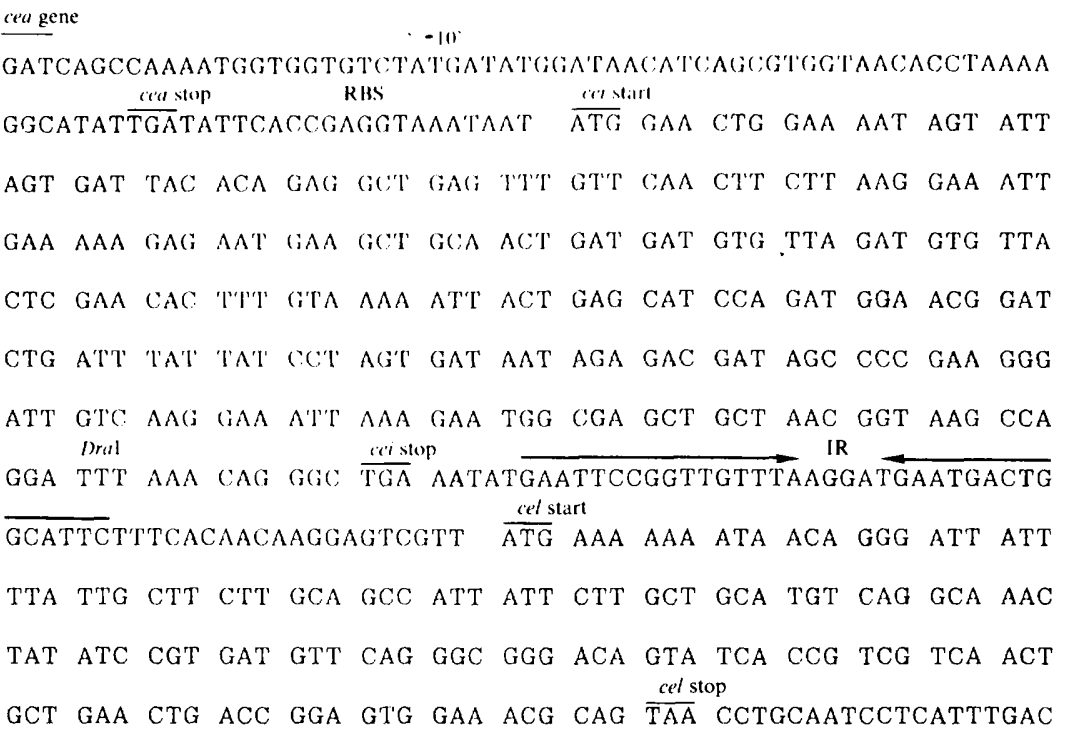
IR

AAGAACAAAGCGTGTCAGGCTGATTCTGACGCGCTTTTTTTGTTGAAGTGCCACAAA AAT'TCCATGTGGGAGATGGGATC

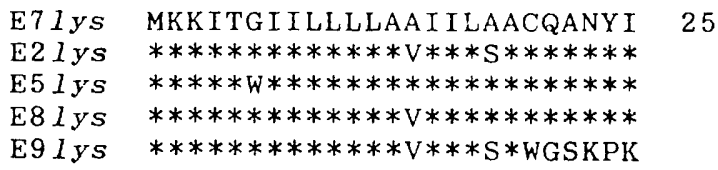

50

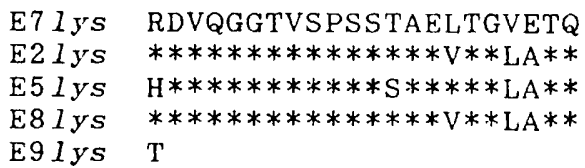

Fig. 7. Homology between $\mathrm{E}$ colicin lysis gene products. The amino acid sequences of the E2, E5, E8 and E9 lysis proteins are shown when they differ from that of the $\mathrm{E} 7$ lysis protein. Identical amino acids are indicated by asterisks.

not known whether the cei gene uses a rare ' -35 ' sequence which differs from the consensus sequence (Rosenberg \& Court, 1979), or whether the ' -35 ' sequence is not necessary for the expression of the cei gene. Two inverted repeat sequences were found immediately after the translational stop signal (TGA) of $c e i$ and that (TAA) of cel (Fig. 5). These two inverted repeat sequences must be the terminators of the respective genes. The sequence data support the finding that no promoter activity is located in plasmid pPPV80 (Fig. 4).

Comparison of the deduced amino acid sequences of the E7 immunity protein and lysis/release protein with those of other immunity and lysis/release proteins (Fig. 6, Fig. 7), showed that the E7 immunity protein is more closely related to the $\mathrm{E} 2$ immunity protein than to the other immunity proteins examined. Their amino acid and DNA sequences have a higher degree of similarity 


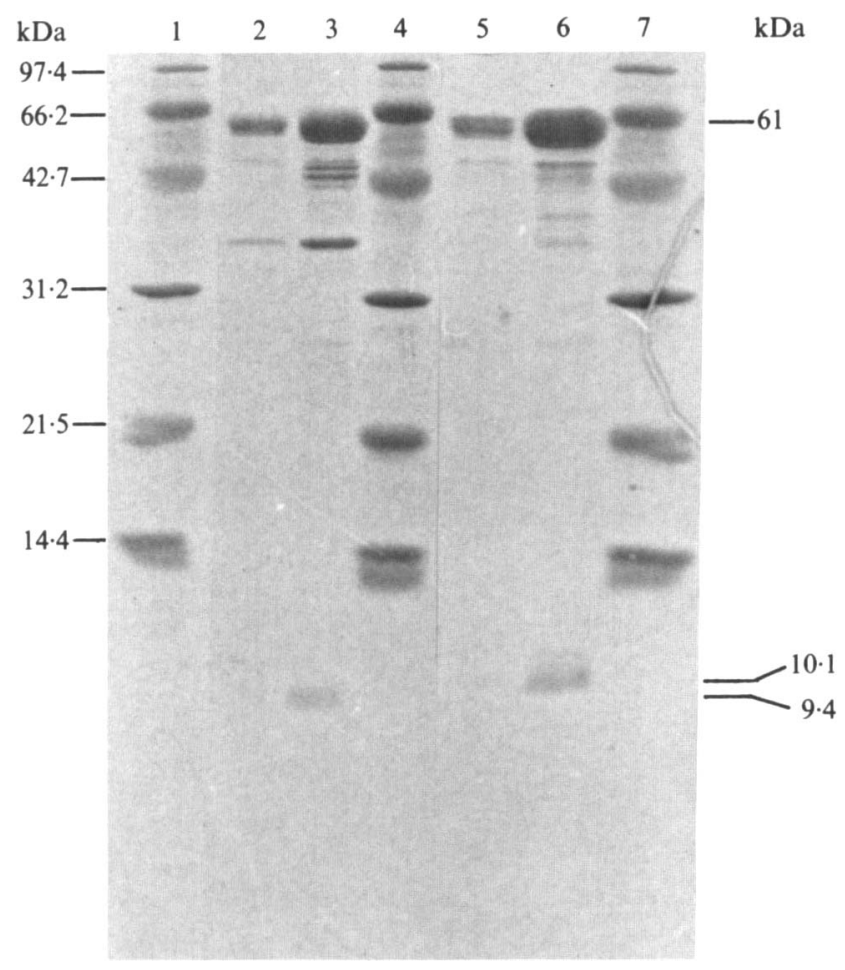

Fig. 8. SDS-PAGE of colicins E7 and E9. The colicins were purified by carboxymethylcellulose column chromatography (see Methods). The concentration of the purified colicins was adjusted to $1 \mu \mathrm{g} \mu \mathrm{l}^{-1}$. Lanes 1, 4 and 7 contain molecular mass markers. Lanes 2 and 3 were loaded with $1 \mu \mathrm{l}$ and $5 \mu 1$ of purified colicin E7, respectively. Lanes 5 and 6 were loaded with $1 \mu \mathrm{l}$ and $5 \mu \mathrm{l}$ of purified colicin E9, respectively.
Table 2. Similarity between $E$ colicin immunity and lysis genes and proteins

PC/Gene, a DNA analysis program from Genetech, was used for the comparison analysis. The amino acid sequences of the E7 immunity protein and E7 lysis protein were deduced from the DNA sequences. The other DNA and amino acid sequences are from: E2, Cole et al. (1985); E8, Uchimura \& Lau (1987); E9, James et al. (1987); E5, Curtis et al. (1989).

\begin{tabular}{lcccc}
\hline \hline & \multicolumn{4}{c}{ Similarity (\%) with other } \\
& E colicin immunity genes and proteins \\
\cline { 2 - 5 } & E2 & E8 & E9 \\
\hline E7 immunity gene & 78 & 73 & 69 \\
E7 immunity protein & 67 & 62 & 61 & \\
& \multicolumn{4}{c}{ Similarity (\%) } \\
& \multicolumn{5}{c}{ E colicin lysis genes and proteins } \\
\cline { 2 - 5 } & E2 & E5 & E8 & E9 \\
\hline E7 lysis gene & 92 & 92 & 92 & 81 \\
E7 lysis protein & 89 & 89 & 92 & 74 \\
\hline \hline
\end{tabular}

$(67 \%$ and $78 \%$, respectively) than the other immunity proteins or genes (Table 2). E7-cel is evidently related to E8-cel, as both the amino acid and DNA sequences show $92 \%$ homology with each other (Table 2). The molecular mass of the $\mathrm{E} 7$ immunity protein deduced from the DNA sequence (Fig. 6) is $9926 \mathrm{Da}$, which agrees well with the

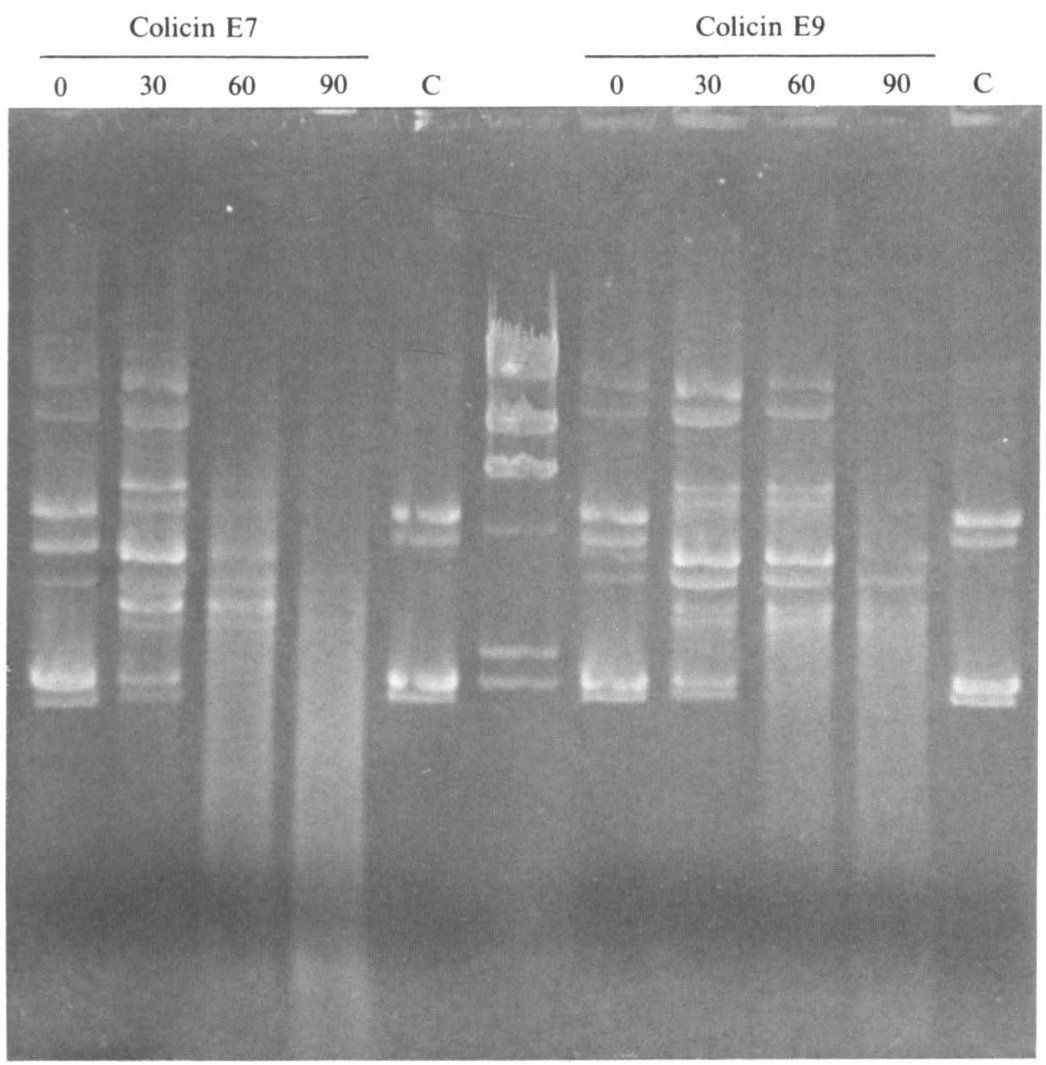

Fig. 9. In vitro biological activity assay of colicins E7 and E9. Colicins E7 and E9 were incubated with pUC18 DNA for $0,30,60$ and $90 \mathrm{~min}$, as indicated. $\mathrm{C}$, Negative controls, which contained no colicin and were incubated at $37^{\circ} \mathrm{C}$ for $90 \mathrm{~min}$. The central lane contains HindIII-digested $\lambda$ DNA. 


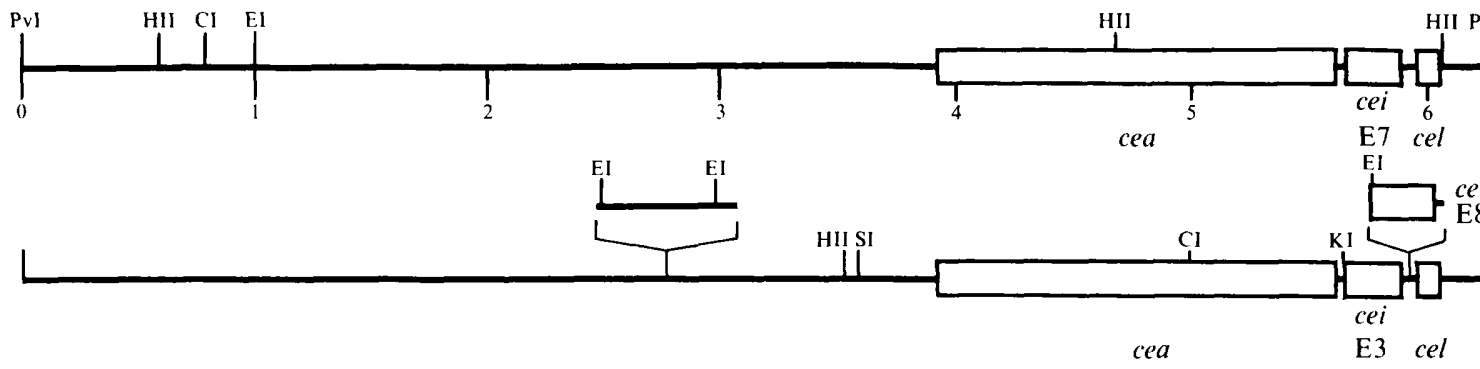

ColE7-K 317

$(6 \cdot 2 \mathrm{~kb})$

ColE3-CA38

$(7.2 \mathrm{~kb})$
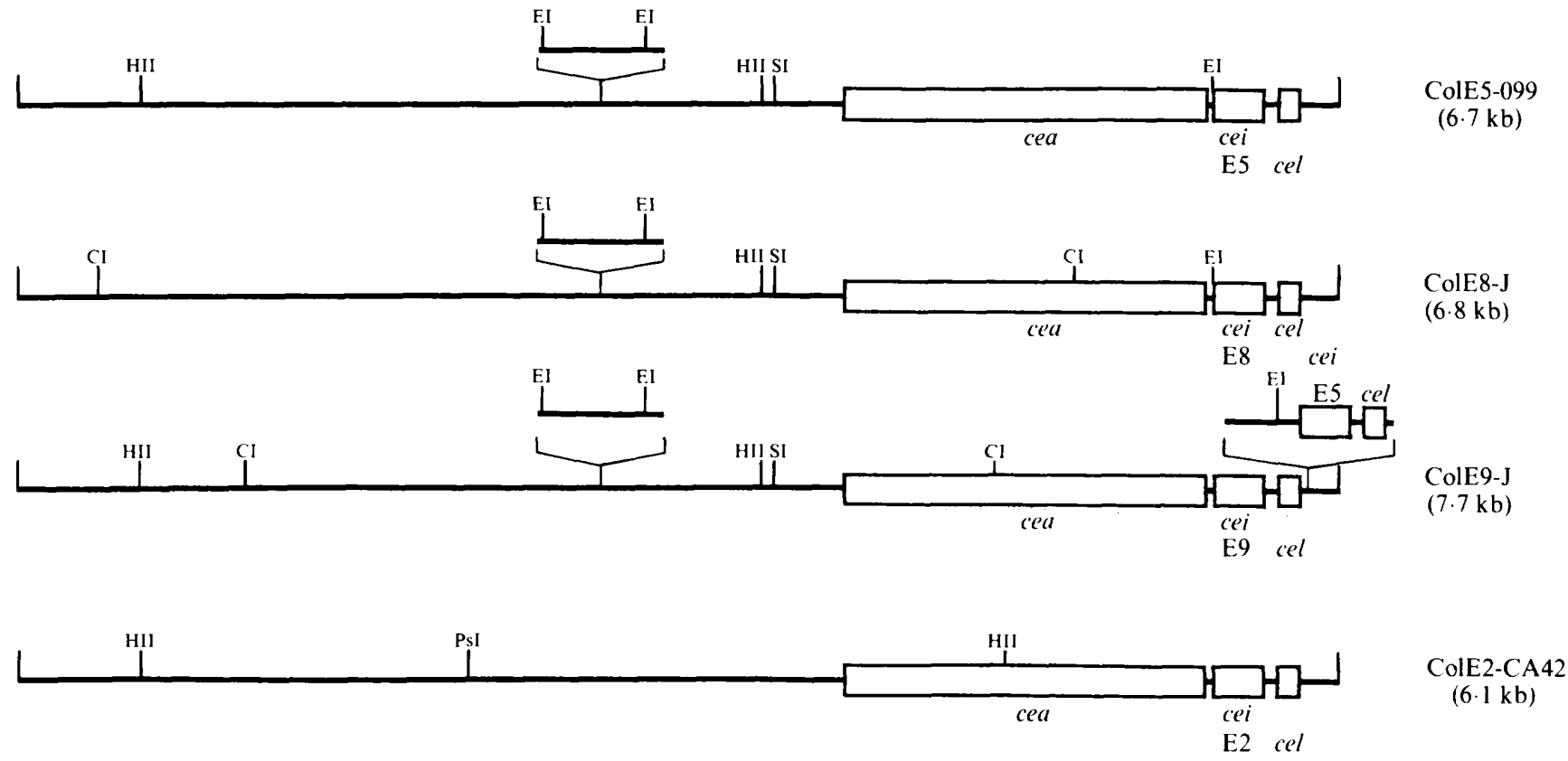

Fig. 10. Evolutionary relationships of the colicin E7 plasmid to some selected E colicin plasmids. The linearized restriction map of ColE7 (this work) was used as a reference. The restriction maps of ColE3-CA38, ColE5-099, ColE8-J and ColE9-J were reported by Chak \& James (1986); that of ColE2-CA42 was reported by Watson et al. (1985). The differences and similarities of the restriction maps of the plasmids are shown. The lines above certain of the plasmids represent the hypothetical insertion of a DNA fragment in the corresponding positions of these plasmids. The boxes represent the colicin operon, comprising the cea, cei and cel genes. The acquired extra cei and cel genes are shown for individual plasmids where appropriate. PvI, PvuI; HII, HincII; EI, EcoRI; CI, ClaI; SI, SmaI ; PsI, PstI; KI, KpnI.

molecular mass $(9 \cdot 4 \mathrm{kDa})$ of this protein determined by SDS-PAGE. The deduced molecular mass of the E7 lysis protein (Fig. 7) is $4872 \mathrm{kDa}$.

\section{Purification and in vitro activity of colicins}

The purity and molecular masses of purified preparations of colicins E7 and E9 were checked by SDS-PAGE (Fig. 8). The molecular mass of colicin E7 and its immunity protein were $61 \mathrm{kDa}$ and $9.4 \mathrm{kDa}$, respectively (the deduced molecular mass from DNA sequence is $9.9 \mathrm{kDa}$ ). The sizes of colicin E9 and its immunity protein were $62 \mathrm{kDa}$ and $10 \cdot 1 \mathrm{kDa}$, respectively.

In the in vitro activity tests for DNAase activity, the amount of the linear form of plasmid DNA increased, accompanied by a decrease in the amount of the covalently closed circular and open circular forms, during the first $60 \mathrm{~min}$ incubation at $37^{\circ} \mathrm{C}$ (Fig. 9). Eventually, most of the plasmid DNA turned into very small fragments forming a smear of DNA visualized by agarose gel electrophoresis. This implied that both colicins were non-specific DNA endonucleases. In the control incubation no change was observed in the plasmid DNA.

\section{Discussion}

The ColE7 plasmid is $6.2 \mathrm{~kb}$ in size, and it encodes a $61 \mathrm{kDa}$ colicin (Fig. 8). The molecular masses of the E7 immunity protein and the E7 lysis protein, deduced from the DNA sequence data, were 9926 and $4872 \mathrm{Da}$, 
respectively. Purified colicins E7 and E9 exhibited DNA endonuclease activity.

The production of colicin by $E$. coli( $\mathrm{pHK} 001)$ was much higher than that by $E$. coli(pHK14), suggesting that the $1.5 \mathrm{~kb}$ Sau3A fragment which was deleted from upstream of the colicin E7 structural gene in pHK 14 may be important for the control of colicin production. This observation was supported by the in vivo promoter activity tests of these recombinant plasmids.

It is not known why the production of colicin by $E$. coli(pPPV-EH1) is not induced by MC. However, the promoter activity of this recombinant plasmid is at a basal level, which was very similar to the basal level activity of recombinant plasmid pPPV-57. It is not known whether the 'SOS' box, or any other regulatory region, has been deleted in pPPV-EH1. The DNA sequence of this region may help to solve this problem. $E$. coli( $\mathrm{pHK} 80)$ was immune to colicin E7, but did not cause cell lysis even after IPTG induction. However, when the $0.65 \mathrm{~kb}$ insert of pHK80 was placed in the same orientation with respect to lac promoter control, cell lysis occurred $60 \mathrm{~min}$ after IPTG induction. This result was similar to previous findings indicating that the immunity gene has its own promoter and that expression of this promoter is constitutive, whereas the cel gene is promoterless (Chak \& James, 1985). The expression of the cel gene is dependent upon transcriptional readthrough from the colicin promoter. This genetic organization is also supported by the in vivo promoter activity tests and the DNA sequence of the cei and cel regions reported in this paper. Although the cel gene is located distal to the cei gene, transcriptional readthrough from the cei promoter alone is not sufficient to result in significant expression of the cel gene. This finding is slightly different from results obtained in studies of the expression of E2-cei (Masaki et al., 1985) and E3-cei (Masaki \& Ohta, 1985), which showed that the presence of an internal promoter of the cei gene was questionable. The BamHI fragment which was used for the promoter activity test of the E2-ceiE2 gene by Masaki et al. (1985) contained the termination sequence located distal to the cei gene, so the promoter activity of the cei gene could not be detected properly. The E3-cei gene (298 bp Sau3A fragment) containing only 42 nucleotides upstream of the initiation codon conferred partial immunity to colicin E3 (Masaki \& Ohto, 1985). This finding may be due to the fact that the putative Pribnow box located at nucleotides -67 to -61 of the initiation start site of the gene E7-cei (this paper) was not included in this Sau3A fragment. The question of whether or not cei genes contain their own promoters may be answered by cloning various DNA fragments containing cei genes from all ColE plasmids into a promoter-probe vector system.

The organization of the ColE7 plasmid and the possible evolutionary relationship of some ColE plasmids is illustrated in Fig. 10. A comparison of the restriction and functional maps of most of the ColE plasmids reveals considerable similarities. In most of the ColE plasmids there is a DNA fragment (roughly $1 \mathrm{~kb}$ in length) located proximal to the $5^{\prime}$ end of the colicin $\mathrm{E}$ structural gene. ColE2 and ColE7 are the only two plasmids which lack this fragment (Fig. 10); these plasmids are about $1 \mathrm{~kb}$ shorter than the other ColE plasmids. This suggests that the upstream sequences of the colicin E2 and colicin E7 structural genes may differ from those of all other ColE plasmids. It is interesting that deletion of a $1.5 \mathrm{~kb}$ Sau $3 \mathrm{~A}$ fragment upstream of the colicin E7 structural gene caused a reduction in colicin production (see Results). The ColE2 and ColE7 plasmids are also the only ColE plasmids in which there is a HincII site in the structural gene (Fig. 1; Watson et al., 1985). It seems reasonable to predict that the structural genes of colicin E2 and colicin E7 are more closely related to each other than to the other E colicin genes.

The sequence data support the idea that the E2 and E7 $c e i$ genes are more closely related than other $\mathrm{E}$ colicin $c e i$. genes. The ColE7 plasmid has a unique EcoRI site at $1.0 \mathrm{~kb}$ and an internal HincII site in the cel gene. The significance of these two characteristics with respect to the position of the ColE7 plasmid in the evolutionary pathway of the ColE plasmids is not known. Further study of the ColE7 plasmid should increase our understanding of the evolutionary origin of the ColE plasmids.

This work was supported by grant NSC79-0412-B010-29 from the National Science Council of the ROC.

\section{References}

Bowman, C. M., Dahlberg, J. E., Ikemura, T., Konisky, J. \& NomURA, M. (1971). Specific inactivation of $16 \mathrm{~S}$ ribosomal RNA induced by colicin E3 in vivo. Proceedings of the National Academy of Sciences of the United States of America 68, 964-968.

BiRnBoim, H. C. (1983). A rapid alkaline extraction procedure for screening plasmid DNA. Methods in Enzymology 100B, 243-255.

CHAK, K.-F. \& JAMES, R. (1984). Localization and characterization of a gene on the ColE3-CA38 plasmid that confers immunity to colicin E8. Journal of General Microbiology 130, 701-710.

CHAK, K.-F. \& JAMES, R. (1985). Analysis of the promoters for the two immunity genes present in the ColE3-CA38 plasmid using two new promoter probe vectors. Nucleic Acids Research 13, 2519-2531.

CHAK, K.-F. \& JAMES, R. (1986). Characterization of the ColE9-J plasmid and analysis of its genetic organization. Journal of General Microbiology 132, 61-71.

Chen, E. Y. \& Seeburg, P. H. (1985). Supercoil sequencing: fast and simple method for sequencing plasmid DNA. DNA 4, 165-170.

Cole, S. T., Saint-Joanis, B. \& Pugsley, A. P. (1985). Molecular characterization of the colicin E2 operon and identification of its products. Molecular and General Genetics 198, 465-472.

COOPER, P. C. \& JAMES, R. (1984). Two new E colicins, E8 and E9, produced by a strain of Escherichia coli. Journal of General Microbiology 130, 209-215. 
Curtis, M. D., JAmes, R. \& CoDdington, A. (1989). An evolutionary relationship between the ColE5-099 and ColE9-J plasmids revealed by nucleotide sequencing. Journal of General Microbiology 135, 2783-2788.

Dretzen, G., Bellard, M., Sassone-Corsi, P. \& Chambon, P. (1981). A reliable method for the recovery of DNA fragments from agarose and acrylamide gels. Analytical Biochemistry 112, 295-298.

FredericQ, P. (1949). Sur la resistance croisée entre colicine E et bacteriophage II. Comptes Rendus des Séances de la Société de biologie 143, $1011-1013$.

Herschman, H. R. \& Helinski, D. R. (1967). Comparative study of the events associated with colicin induction. Journal of Bacteriology 94, 691-699.

JAKes, K., ZINDER, N. D. \& BoON, T. (1974). Purification and properties of colicin E3 immunity protein. Journal of Biological Chemistry 249, 438-444.

James, R., JaR VIS, M. \& BARKer, D. F. (1987). Nucleotide sequence of the immunity and lysis region of the ColE9-J plasmid. Journal of General Microbiology 133, 1553-1562.

KoNISKY, J. (1982). Colicins and other bacteriocins with established modes of action. Annual Review of Microbiology 36, 125-144.

Maniatis, T., Fritsch, E. F. \& SAmbrooK, J. (1982). Molecular Cloning - a Laboratory Manual. Cold Spring Harbor, NY: Cold Spring Harbor Laboratory.

MASAKI, H. \& OHTA, T. (1985). Colicin E3 and its immunity genes. Journal of Molecular Biology 182, 217-227.

MASAKI, H., TOBA, M. \& OHTA, T. (1985). Structure and expression of the ColE2-P9 immunity gene. Nucleic Acids Research 13, 1623-1635.

McKenny, K., Schimatake, H., Court, D., Scheissner, V., Brady, C. \& ROSENBERG (1981). A system to study promoter and terminator signals recognised by Escherichia coli RNA polymerase. In Gene Amplification and Analysis, vol. 2, pp. 383-415. Edited by J. G. Chirikjian \& T. Papas. Amsterdam: Elsevier-North Holland.

Miller, J. H. (1972). Experiments in Molecular Genetics. Cold Spring Harbor, NY: Cold Spring Harbor Laboratory.

Pugsley, A. P. \& Oudega, B. (1987). Methods for studying colicins and their plasmids. In Plasmids - a Practical Approach, pp. 105-161. Edited by K. G. Hardy. Oxford \& Washington, DC: IRL Press.

REEVES, P. (1965). The adsorption and kinetics of killing by colicin CA 42-E2. Australian Journal of Experimental Biology and Medical Science 43, 191-200.

ROSENBERG, M. \& CoURT, D. (1979). Regulatory sequences involved in the promotion and termination of RNA transcription. Annual Review of Genetics 13, 319-353.

Sanger, F., Nicklen, S. \& Coulson, A. R. (1977). DNA sequencing with chain-terminating inhibitors. Proceedings of the National Academy of Sciences of the United States of America 74, 5463-5467.

Schaller, K. \& Momura, M. (1976). Colicin E2 is a DNA endonuclease. Proceedings of the National Academy of Sciences of the United States of America 73, 3989-3993.

TABOR, S. \& RICHARDSON, C. C. (1987). DNA sequence analysis with a modified bacteriophage T7 DNA polymerase. Proceedings of the National Academy of Sciences of the United States of America 84, 4767-4771.

Toba, M., Masaki, H. \& OHTA, T. (1988). Colicin E8, a DNase which indicates an evolutionary relationship between colicins E2 and E3. Journal of Bacteriology 170, 3237-3242.

ToKUDA, H. \& KonISKY, J. (1979). Effect of colicins Ia and E1 on ion permeability of liposomes. Proceedings of the National Academy of Sciences of the United States of America 76, 6167-6171.

UChimURA, T. \& LAU, P. (1987). Nucleotide sequences from the colicin E8 operon: homology with plasmid ColE2-P9. Molecular and General Genetics 209, 489-493.

Watson, R., Rowsome, W., TSAo, J. \& Visentin, L. P. (1981). Identification and characterization of Col plasmids from classical colicin E-producing strains. Journal of Bacteriology 147, 569-577.

Watson, R., Vernet, T. \& Visentin, L. P. (1985). Relationships of the Col plasmids E2, E3, E4, E6 and E7: restriction mapping and colicin gene fusions. Plasmid 13, 205-210.

Yanisch-Perron, C., Vieira, J. \& Messing, J. (1985). Improved M13 phage cloning vectors and host strains: nucleotide sequences of the M13mp18 and pUC19 vectors. Gene 33, 103-119. 